\title{
RISK FACTORS AND DETERMINANTS OF SEX TRADE BEHAVIOURS AMONG THE MALE HOMELESS POPULATION IN IRAN
}

\section{CZYNNIKI RYZYKA I DETERMINANTY ZACHOWAŃ ZWIAZANE ZE ŚWIADCZENIEM USŁUG SEKSUALNYCH PRZEZ BEZDOMNYCH MĘŻCZYZN W IRANIE}

\author{
Masumeh Ghazanfarpour ${ }^{1} \mathbb{D}$, Jamal Aliabadi ${ }^{2}$, Afshar Sahmahammadi $^{3}$, Sara Sadr $^{4}$ (D), Hamed Jafarpour ${ }^{4} \mathbb{D}$, \\ Sara Mohammadnia ${ }^{5}$, Saeed Dashti Dargahloo ${ }^{4}$ ID , Shahrzad Khosravifar ${ }^{6}$ ID, Masoudeh Babakhanian ${ }^{7}$ ID \\ ${ }^{1}$ Student Research Committee, Kerman University of Medical Sciences, Kerman, Iran \\ ${ }^{2}$ Tehran of Welfare Organization, Allameh Tabataba’i University of Social Work, Pakdasht, Tehran, Iran \\ ${ }^{3}$ Clinical Research Development Center, Imam Ali and Taleghani Hospital, Kermanshah University of Medical Sciences, \\ Kermanshah, Iran \\ ${ }^{4}$ Student Research Committee, Faculty of Medicine, Mazandaran University of Medical Sciences, Sari, Iran \\ ${ }^{5}$ Imam Hossein Hospital, Iran University of Medical Science, Tehran, Iran \\ ${ }^{6}$ Ali Asghar Children Hospital, Iran University of Medical Science, Tehran, Iran \\ ${ }^{7}$ Student Research Committee, Psychiatry and Behavioral Research Centre, Addiction Institute, Mazandaran University of Medical \\ Sciences, Sari, Iran
}

Alcohol Drug Addict 2021; 34 (1): 79-90 DOI: https://doi.org/10.5114/ain.2021.107712

\section{Abstract}

Introduction: This study aimed to investigate sex-related behaviours and the risk factors for prostitution and its related variables among homeless men in Tehran.

Material and methods: This cross-sectional study was performed on 247 homeless men (18-55 years old) living in temporary shelters in

\section{Streszczenie}

Wprowadzenie: Badano bezdomnych mężczyzn żyjących w Teheranie - zachowania seksualne, czynniki ryzyka prostytucji i związane $\mathrm{z}$ tym zmienne.

Material i metody: W latach 2017-2018 przeprowadzono badanie przekrojowe na grupie 247 bezdomnych mężczyzn (18-55 lat) mieszkających w tym-

Correspondence to/Adres do korespondencji: Masoudeh Babakhanian, Student Research Committee, Psychiatry and Behavioral Research Centre, Addiction Institute, Zare Hospital, Mazandaran University of Medical Sciences, Sari, 4843185774, Iran, phone: +981133285659, e-mail: babakhanian.m@gmail.com

Authors' contribution/Wkład pracy autorów: Study design/Koncepcja badania: M. Ghazanfarpour, S. Khosravifar, M. Babakhanian; Data collection/Zebranie danych: J. Aliabadi, H. Jafarpour, S. Mohammadnia; Statistical analysis/Analiza statystyczna: A. Shahmohammadi, H. Jafarpour; Data interpretation/Interpretacja danych: M. Ghazanfarpour, S. Sadr, S.D. Dargahloo, M. Babakhanian; Acceptance of final manuscript version/Akceptacja ostatecznej wersji pracy: M. Ghazanfarpour, J. Aliabadi, A. Shahmohammadi, S. Sadr, H. Jafarpour, S. Mohammadnia, S.D. Dargahloo, S. Khosravifar, M. Babakhanian; Literature search/Przygotowanie literatury: M. Ghazanfarpour, M. Babakhanian; Funds collection/Pozyskanie finansowania: M. Babakhanian.

No ghostwriting and guest authorship declared./Nie występują zjawiska ghostwriting i guest authorship.

Submitted/Otrzymano: 05.01.2020 • Accepted/Przyjęto do druku: 19.10.2020

(c) 2021 Institute of Psychiatry and Neurology. Production and hosting by Termedia sp. z o.o.

This is an open access article under the CC BY-NC-ND license (http://creativecommons.org/licenses/by-nc-nd/4.0/) 
southeast Tehran between 2017 and 2018. Data were collected using a semi-structured interview containing demographic information, medical history and the level of exposure to prostitution. Data analysis was conducted by SPSS-22 using descriptive statistics, correlation analysis and multivariable regressions.

Results: Participants had a mean age of 37.5 years. The mean duration of homelessness was 3.7 years. Most participants were single, had primary education and a history of imprisonment. The most common reason for prostitution was poverty especially considering the need to financially support addiction mostly to methamphetamine, heroin and cigarettes. We found a correlation between prostitution and risky sexual acts, substance abuse, psychological and mental health disorders and infection $(p<0.05)$.

Discussion: As has also been shown in other studies, mental health issues and psychoactive substance abuse increase the risk for prostitution. Homelessness is associated with substance abuse and prostitution is a major source of income for homeless individuals. So mental disorders, substance abuse and homelessness form a vicious cycle that exacerbate one another and heighten the risks and prevalence of prostitution.

Conclusions: Given the rice in homelessness rate and consequently prostitution, transmission of HIV/AIDS and hepatitis has increased. The provision of housing, job opportunities, social and medical support can protect the homeless from mental health disorders and drug abuse and the chance of risky sexual acts can be reduced.

Keywords: Prostitution, Homelessness, Iran, Streetworking, Sex-trade, sex transmitted disease. czasowych schroniskach w południowo-wschodniej części Teheranu. Częściowo ustrukturyzowany wywiad zawierał pytania dotyczące danych społeczno-demograficznych, stanu zdrowia i poziomu zagrożenia prostytucją. W analizie danych posłużono się SPSS-22, przy użyciu statystyk opisowych, analizy korelacji i wielowymiarowych regresji.

Wyniki: Średnia wieku uczestników wynosiła 37,5 roku, a średni czas trwania bezdomności - 3,7 roku. Większość $\mathrm{z}$ nich to osoby samotne $\mathrm{z}$ wykształceniem podstawowym i $\mathrm{z}$ doświadczeniem pobytu $\mathrm{w}$ więzieniu. Najczęstszym powodem uprawiania prostytucji przez bezdomnych było ubóstwo, a w szczególności konieczność zaopatrzenia się w substancje, od których byli uzależnieni, głównie metamfetaminę, heroinę i tytoń (papierosy). Stwierdzono korelację między prostytucją a ryzykownymi zachowaniami seksualnymi, nadużywaniem narkotyków, zaburzeniami psychicznymi i infekcjami $(p<0,05)$.

Omówienie: Jak wykazano również w innych badaniach, problemy psychiczne i nadużywanie substancji psychoaktywnych stanowią czynnik ryzyka prostytucji. Bezdomność wiąże się z nadużywaniem substancji psychoaktywnych, a prostytucja jest głównym źródłem dochodu osób bezdomnych. Tak więc zaburzenia psychiczne, nadużywanie narkotyków i bezdomność tworzą błędne koło - pobudzają się wzajemnie, zwiększając ryzyko prostytucji i jej rozpowszechniania.

Wnioski: Bezdomność, a w konsekwencji prostytucja bardzo ułatwiają rozprzestrzenianie się HIV/ AIDS i zapalenia wątroby. Zapewnienie dachu nad głową, możliwość zatrudnienia oraz wsparcie społeczne i medyczne mogłyby chronić bezdomnych przed zaburzeniami psychicznymi i nadużywaniem narkotyków, zmniejszając tym samym niebezpieczeństwo ryzykownych zachowań seksualnych.

Słowa kluczowe: prostytucja, bezdomność, Iran, prostytucja uliczna, świadczenie usług seksualnych, choroby przenoszone drogą płciową.

\section{- INTRODUCTION}

In recent years, homelessness, a growing global urban problem, has received attention from a social perspective in various studies. Homelessness is defined as the forced spending of nights on the streets without proper shelter $[1,2]$.
Since the start of modernisation in Iran, there has been an increase in the rate of migration to larger cities of the country, most notably the capital city of Tehran. The ever-growing income gap has given rise to new phenomena, such as ghettos, slums dwelling, and an increasing rate of homelessness. Only in 2003 was homelessness addressed 
as a real social issue in Iran, following the death of a number of homeless men during a cold Tehran night [3].

The bulk of studies have shown that the underlying causes of homelessness are family disputes, addiction, divorce, unemployment, low education, poverty and sexual and emotional needs $[1,4]$. Bisexuality has also been identified as a risk factor for homelessness in an Iranian study [4].

The underlying causes and risk factors for homelessness can be classified in two interacting domains of individual and structural factors. Individual factors include poverty, personal history of violence, early-childhood adverse experiences, past history of criminal charges, mental health issues and a history of substance abuse.

Studies show that the most common primary individual risk factors for homelessness in young people (12-25 years of age) are victimisation in family conflicts, having a non-heterosexual identity and a history of being in the care of child welfare systems. Structural factors that promote homelessness include unavailability of appropriate housing, lack of employment opportunities for low-skilled workers and lack of income support [5].

Studies show that the mortality rate among the homeless is especially high among younger individuals, which can be caused by the higher rate of infectious diseases like HIV and tuberculosis, ischemic heart disease, substance abuse, unintentional injuries, suicide and homicide. On the other hand, poverty, homelessness, depression and substance abuse form a vicious cycle that further undermines quality of life and emotional and social status. The health (especially mental health) status of the homeless is further compromised by inadequate access to healthcare, which challenges the provision of medication to this population and also hinders completion of therapy [5].

The few studies that have explored homelessness in Iran show a male predominance in the homeless population. However, there is no national official headcount of this population [3]. The homeless are at a greater risk of turning to prostitution, as they are more likely to engage in relations with multiple sexual partners [6]. According to global statistics, female prostitutes vastly outnumber male prostitutes [7] although the number of men engaging in prostitution is on the rise.

Female prostitution is often propagated by poverty, and some single mothers commit to prostitution as a last resort to provide for their children in spite of the associated social stigma all the while trying to conceal their identity as a street-worker [8].

In Iran, male prostitutes provide sexual services to men and sometimes to women [9]. Poverty, illiteracy, a wide range of sexual violence in a male dominant society, and the following stigma that marginalises woman prostitutes (in addition to eliminating other income routes), are some of the reasons that women in a third world country become and remain prostitutes [10]. Financial pressure to support addiction, especially cocaine addiction, is also an incentive to prostitution [11]. There have been few studies that explored prostitution in men, and those are primarily focused on regions like the Americas, Europe (i.e., United Kingdom, Netherlands) and Southeast Asia (i.e., India, Pakistan, and Afghanistan). In some countries in Southeast Asia like Afghanistan and Sri Lanka, boys are more likely than girls to be involved in prostitution and constitute half or more than half of all child prostitutes.

Homelessness is a significant risk factor for prostitution in boys. In middle-eastern societies where men can be rejected and abandoned because of their homosexuality, the subsequent homelessness can result in a higher rate of prostitution as a commercial sexual act and a situational response to homelessness. Among the homeless youth, prostitution is overrepresented by boys [12]. The desire for intimacy and the sense of social isolation are some of the reasons for prostitution among homeless men often associated with emotional, financial, and physical hazards [13]. However, some studies have also demonstrated that involvement in sexual behaviours for the purpose of earning money or obtaining drugs are closely correlated with a lack of shelter [6].

Among intravenous drug users, homelessness is considered a strong predictor of dangerous sexual behaviours [14] and excessive drug injection increases the likelihood of having multiple sexual partners [15]. Since these men's partners are often also grappling with substance abuse, they are less likely to use condoms [16]. Moreover, they are less likely to perform protected sex in a bid to give their female partners more pleasure [17]. Therefore drug injection and unprotected sex can be the main route of HIV transmission [18]. 
Table I. Descriptive statistics and demographic characteristics

\begin{tabular}{|c|c|c|}
\hline Variable/Type & $n$ & $\%$ \\
\hline \multicolumn{3}{|l|}{ Age } \\
\hline $20-29$ & 41 & 17.0 \\
\hline $30-39$ & 120 & 49.8 \\
\hline $40-49$ & 58 & 24.1 \\
\hline$\geq 50$ & 22 & 9.1 \\
\hline \multicolumn{3}{|l|}{ Education } \\
\hline Primary school & 104 & 46.1 \\
\hline High school & 74 & 30.0 \\
\hline University degree & 28 & 11.3 \\
\hline$M / D^{1}$ & 31 & 12.6 \\
\hline \multicolumn{3}{|l|}{ Family information } \\
\hline \multicolumn{3}{|l|}{ Marital status } \\
\hline Single or divorced & 135 & 54.7 \\
\hline Married & 90 & 36.4 \\
\hline \multicolumn{3}{|l|}{ Number of children } \\
\hline 1 & 61 & 24.7 \\
\hline 2 & 46 & 18.6 \\
\hline 3 & 19 & 7.7 \\
\hline 4 and more & 5 & 2.0 \\
\hline \multicolumn{3}{|l|}{ Contact with family } \\
\hline Yes $^{2}$ & 113 & 45.7 \\
\hline No & 55 & 22.3 \\
\hline \multicolumn{3}{|l|}{ Job status } \\
\hline Employed & 2 & 0.8 \\
\hline $\begin{array}{l}\text { Prostitution or otherwise } \\
\text { unemployed }\end{array}$ & 245 & 99.2 \\
\hline $\begin{array}{l}\text { With any form of health } \\
\text { insurance }\end{array}$ & 56 & 22.7 \\
\hline \multicolumn{3}{|l|}{ Homelessness information } \\
\hline $\begin{array}{l}\text { Mean duration } \\
\text { of homelessness }\end{array}$ & \multicolumn{2}{|c|}{3.7 years $(S D=5.4)$} \\
\hline \multicolumn{3}{|l|}{ Reasons for homelessness } \\
\hline $\begin{array}{l}\text { Divorce and family } \\
\text { disputes }\end{array}$ & 3 & 1.2 \\
\hline Drug abuse & 44 & 17.8 \\
\hline $\begin{array}{l}\text { Mental health } \\
\text { disorders }\end{array}$ & 1 & 0.4 \\
\hline Poverty & 10 & 4 \\
\hline $\begin{array}{l}\text { Rejection by family and } \\
\text { society }^{5}\end{array}$ & 6 & 2.4 \\
\hline $\begin{array}{l}\text { Low level of comfort at } \\
\text { home }^{6}\end{array}$ & 1 & 0.4 \\
\hline $\begin{array}{l}\text { As a way of bettering } \\
\text { their family's } \text { lot }^{7}\end{array}$ & 1 & 0.4 \\
\hline M/D & 179 & 72.5 \\
\hline
\end{tabular}

Table I. Cont.

${ }^{1} M / D$ missing data. ${ }^{2}$ Contact with family was defined as visits to home and family members. ${ }^{3}$ Prostitution and related jobs that would negatively affect social image. ${ }^{4}$ Non-severe mental disorders that would not render the individual dysfunctional. ${ }^{5}$ Some individuals left home over disputes or had been shunned and expelled from their home by family. ${ }^{6} \mathrm{~A}$ very bad domestic material situation may lead an individual to leave home in the hope of better earnings or even better living arrangements. ${ }^{7}$ Some individuals may believe their absence from home will result in a better living situation for their families in cases of addiction and poverty.

Male prostitutes, like women, need strategies and interventions to reduce the risk of harm on their health. Given the increasing trend of drug use in Iran over the past few years, identifying the risk factors and social harm for the homeless can help develop strategies to alleviate and overcome these problems. To the best of our knowledge, our study is the first to explore this subject in Iran. Most addicts in Iran reveal a negative attitude towards using condoms and as a result, sexually transmitted infections and AIDS are a major cause of death among these populations in developing countries like Iran $[15,19]$. Homelessness is not merely a lack of shelter, and it encompasses various other phenomena like marginalisation, poor job prospects, financial dependency, higher rates of risk-taking behaviour and a tendency for victimisation [8]. Thus to protect women and men, it is essential to offer Iranian men health education and conduct programmes to relieve the harm associated with homelessness.

The current study aims to investigate sex-related behaviours of homeless men in Tehran, and also to determine the risk factors and variables related to prostitution among the homeless people.

\section{- MATERIAL AND METHOdS}

\section{Sample selection}

This cross-sectional study was carried out on 247 homeless men at a temporary shelter in the south of Tehran between 2017 and 2018 . The temporary shelters, which operate under the supervision of Welfare Organization and the Municipality of Iran, offer services to homeless people in form of drug withdrawing counselling, psychotherapy and health services. Sampling was conducted using the availability sampling method after considering inclusion and exclusion criteria. 
Table II. Descriptive statistics of subjects' medical history, mental health disorder history, substance use, sexually risky behaviours and reasons for and against prostitution

\begin{tabular}{|c|c|c|}
\hline Variable/Type & $n$ & $\%$ \\
\hline \multicolumn{3}{|l|}{ Physical and infection state } \\
\hline Erectile disorders & 17 & 6.9 \\
\hline Heart and pulmonary disorders & 26 & 10.5 \\
\hline HIV (human immunodeficiency virus) & 2 & 0.8 \\
\hline HPV (human papilloma virus) & 1 & 0.4 \\
\hline HCV (hepatitis C virus) & 3 & 1.2 \\
\hline \multicolumn{3}{|l|}{ Mental health disorder history } \\
\hline Depression & 42 & 17.0 \\
\hline Personality disorder & 14 & 5.6 \\
\hline History of suicide attempts & 54 & 21.8 \\
\hline Men with frequent hospitalisation in psychiatric wards & 13 & 5.2 \\
\hline \multicolumn{3}{|l|}{ Substance use } \\
\hline Opioids & 51 & 20.6 \\
\hline Alcohol & 25 & 10.0 \\
\hline Cigarettes (tobacco) & 225 & 91.0 \\
\hline Methamphetamine (crystal) & 175 & 70.1 \\
\hline Methadone $^{1}$ & 94 & 38.0 \\
\hline Hashish & 22 & 9.0 \\
\hline Buprenorphine & 9 & 3.6 \\
\hline Heroin & 128 & 51.8 \\
\hline Injection as the administration route & 19 & 7.7 \\
\hline Needle sharing ${ }^{2}$ & 12 & 4.8 \\
\hline \multicolumn{3}{|l|}{ Sexually risky behaviours (past six months) } \\
\hline Multiple sexual partners $^{3}$ & 20 & 8.1 \\
\hline Unprotected sex & 201 & 81.4 \\
\hline History of anal sex & 29 & 11.7 \\
\hline Anal sex after drug use & 24 & 10.0 \\
\hline \multicolumn{3}{|l|}{ Social support } \\
\hline Having a family to possibly return to at some point & 66 & 26.7 \\
\hline Any support except a warm, welcoming home (e.g. friends, the community) & 94 & 38.0 \\
\hline \multicolumn{3}{|l|}{ Reason for prostitution } \\
\hline To support substance use financially & 31 & 12.5 \\
\hline Poverty & 71 & 28.7 \\
\hline Pleasure & 1 & 0.4 \\
\hline Compulsion & 1 & 0.4 \\
\hline Unemployment & 3 & 1.2 \\
\hline Lack of a shelter & 4 & 1.6 \\
\hline Revenging the community by spreading AIDS & 2 & 0.8 \\
\hline To provide for their family ${ }^{4}$ & 8 & 3.2 \\
\hline No sense of guilt or shame & 2 & 0.8 \\
\hline
\end{tabular}


Table II. Cont.

\begin{tabular}{|c|c|c|}
\hline \multicolumn{3}{|l|}{ Factors that discourage prostitution } \\
\hline Lack of self-confidence & 15 & 6.0 \\
\hline Fear of contracting an STD ${ }^{5}$ and pain & 5 & 2.0 \\
\hline Moral and personal beliefs & 6 & 2.4 \\
\hline High income $^{6}$ & 14 & 5.6 \\
\hline Efficient access to substance of use ${ }^{7}$ & 11 & 4.4 \\
\hline Past negative experience with prostitution & 1 & 0.4 \\
\hline Past experience of pain & 1 & 0.4 \\
\hline
\end{tabular}

${ }^{1}$ An artificially manufactured opioid substance. ${ }^{2}$ Needle sharing is also considered a risky behaviour. ${ }^{3}$ More than one sexual partner in the past 12 months. ${ }^{4} \mathrm{Men}$ who have resorted to prostitution in order to provide for their family because they fear being rejected and shunned by their family if they cannot provide financial support. ${ }^{5}$ Sexually transmitted disease. ${ }^{6 \& 7}$ Low income and poverty have been a major incentive for prostitution, therefore a high enough income that can also support an individual's substance use can act as a preventive factor.

\section{Participants' characteristics}

The inclusion criteria were: 1) male gender, 2) 18 to 55 years of age, 3 ) homeless in the previous six months and 4) were living at the temporary shelter at the time of the study. The exclusion criteria was a history of severe mental disorders that would impair one's ability to perform the basic functions needed to live alone like 1) schizophrenia, 2) mania (in untreated bipolar affective disorder), 3) psychotic disorders and 4) conditions that cause delusion and/or hallucinations, catatonia or delirium.

\section{Data collection tools}

The data was collected using a researcher-made questionnaire completed by social workers, based on face-to-face interviews with participants in the temporary shelter.

The questionnaire comprised of 4 sections:

Demographic background. Age (18 to 55 years old), marital status ( single, married, divorced), educational level, occupation and status of insurance, number of children, duration of homelessness and reason for homelessness (Table I).

Past medical history. Physical health (chronic disease, erectile dysfunction, HIV infection, hepatitis and genital warts), mental health status and history of hospitalisation in a psychiatric ward (history of self-harm and suicide attempts, depression and personality disorders), substance abuse, intravenous substance injection and needle sharing (which is also considered a risky behaviour) and history of high-risk sexual behaviours (anal sex, multiple sexual partners, unprotected sex, anal sex after drug use). The items in the questionnaire were respond- ed by choosing 'yes' or 'no' alternatives (Table II). (It should be noted that participants' responses in this section were verified and completed based on their previous medical records kept at the shelter if they were made available by the participant, and after each individual's consent for the documents to be used in this study).

Social support. Friendship networks, using job hunting networks and possibility of returning to their family (Table II).

We also asked our participants to express what they considered their fundamental needs in an open-ended question.

Exposure to prostitution. The factors facilitating prostitution, or obstacles facing the individual, and factors that may discourage each person from prostitution (which is described in detail in Table II).

The contents of the questionnaire were retested on 14 subjects after 14 days. The Cronbach's a (0.91) and ICC $=0.917(0.73-0.97)$ were calculated.

\section{Ethical considerations}

All study procedures were conducted on human participants in compliance with ethical standards approved by the Institutional/National Research Committee, the 1964 Declaration of Helsinki and its later amendments, or comparable ethical standards. Study participation did not jeopardize participants' safety in any way. All participants provided written consent prior to involvement in the study, remained anonymous and were not paid for participation. This study was conducted at the Mazandaran University of Medical Sciences, Iran in 2017 (ethics code: IR.MAZUMS.REC.1396.114). 
Risk factors and determinants of sex trade behaviours among the male homeless population in Iran

Table III. Correlation matrix of prostitution, mental health disorders, sexually risky behaviour, physical and infectious status and substance abuse

\begin{tabular}{|c|c|c|c|c|c|}
\hline & $\begin{array}{l}\text { High-risk sexual } \\
\text { behaviours }\end{array}$ & $\begin{array}{l}\text { Substance } \\
\text { abuse }\end{array}$ & $\begin{array}{l}\text { Mental health } \\
\text { disorders }\end{array}$ & $\begin{array}{l}\text { Physical and } \\
\text { infectious state }\end{array}$ & Prostitution \\
\hline $\begin{array}{l}\text { High-risk sexual } \\
\text { behaviours }\end{array}$ & 1 & $\begin{array}{l}R=0.002 \\
\text { Sig }=0.9\end{array}$ & $\begin{aligned} R & =0.27 \\
\text { Sig } & =0.000\end{aligned}$ & $\begin{aligned} R & =0.2 \\
\text { Sig } & =0.002\end{aligned}$ & $\begin{aligned} R & =0.47 \\
\mathrm{Sig} & =0.000\end{aligned}$ \\
\hline Substance abuse & & 1 & $\begin{aligned} R & =0.37 \\
\text { Sig } & =0.000\end{aligned}$ & $\begin{array}{l}R=-0.04 \\
\text { Sig }=0.4\end{array}$ & $\begin{aligned} R & =0.27 \\
\text { Sig } & =0.000\end{aligned}$ \\
\hline Mental health-disorders & & & 1 & $\begin{array}{l}R=0.15 \\
\text { Sig }=0.02\end{array}$ & $\begin{aligned} R & =0.30 \\
\mathrm{Sig} & =0.000\end{aligned}$ \\
\hline $\begin{array}{l}\text { Physical and infectious } \\
\text { state }\end{array}$ & & & & 1 & $\begin{aligned} R & =0.2 \\
\text { Sig } & =0.000\end{aligned}$ \\
\hline Prostitution & & & & & 1 \\
\hline
\end{tabular}

The controlled variables were selected based on statistical analysis of similar studies and expert's opinions.

Table IV. Multivariate logistic regression analysis predicting relationships between the prostitution-related variables

\begin{tabular}{|c|c|c|c|c|c|c|c|}
\hline \multirow[t]{2}{*}{ Variable } & \multirow[t]{2}{*}{ B } & \multirow[t]{2}{*}{ Std. error ${ }^{1}$} & \multirow[t]{2}{*}{$d f^{2}$} & \multirow[t]{2}{*}{$\operatorname{EXP}(B)^{3}$} & \multirow[t]{2}{*}{$p$-value } & \multicolumn{2}{|c|}{$95 \% \mathrm{Cl}^{4}$ for EXP (B) } \\
\hline & & & & & & Lower & Upper \\
\hline Mental health disorders & -3.536 & 1.043 & 1 & 0.029 & 0.001 & 0.004 & 0.225 \\
\hline Drug abuse & -3.775 & 1.485 & 1 & 0.023 & 0.011 & 0.817 & 11.996 \\
\hline Job status & 0.000 & 0.000 & 1 & 1.000 & 0.6 & 1.000 & 1.000 \\
\hline Marital status & -0.969 & 1.127 & 1 & 0.380 & 0.3 & 0.042 & 3.458 \\
\hline Age & 1.141 & 0.686 & 1 & 3.130 & 0.09 & 0.817 & 11.996 \\
\hline
\end{tabular}

${ }^{1}$ Std. error (standard error): Is the standard deviation of sampling distribution or an estimate of the standard deviation. ${ }^{2} d f$ (degree of freedom): Is the number of values in the final calculation of a variating statistic. ${ }^{3} \mathrm{EXP}(\mathrm{B})$ : Exponentiation of the $B$ coefficient. ${ }^{4} \mathrm{CI}$ (confidence interval): Based on the statistical analysis of the data, this number proposes a range of plausible values for an unknown parameter.

The controlled variables were selected based on statistical analysis of similar studies and expert's opinions.

\section{Statistical analyses}

The descriptive analysis, Pearson correlation test and multivariate logistic regression analysis were conducted by SPSS 22. The odds ratios and a confidence interval of $95 \%$ ( $\mathrm{Sig}=0.05)$ were used for the statistical analyses. Considering the nature of studies like this, we expected reluctancy on part of our participants regarding answering some of the questions and we expected to have considerable missing data [20]. Since the missing data in this study did not affect other dependent variables, we used the traditional method of "omitting missing data" [21], which in turn decreased the actual sample size and therefore the statistical value of our results.

\section{- Results}

The participants included 247 homeless men with a mean age of $37.5(\mathrm{SD}=9.6)$, living in southeastern Tehran. The average monthly income of participants was about ten million Rials (\$40) and they had $1.8(\mathrm{SD}=1)$ children on average. In this study 113 participants (45.7\%) had a history of imprisonment with a mean prison term of 3.7 years. Nearly half of participants had primary education $(n=104,46.1 \%)$ and $54.7 \%(n=135)$ were single. Also, $0.8 \%$ and $1.2 \%$ were infected with HIV and hepatitis C, respectively $(n=2$ and 3$)$. The demographic characteristics of subjects are listed in Table I.

Since there are some missing data, the number of participants in categories of age (241), education (237), marital status (225), etc. do not match the total number of participants (247).

The most prevalent psychiatric finding among participants was a positive history of suicide attempts $(n=54,21.8 \%)$. Smoking and methamphetamine use were the most common form of substance abuse among the participants $(n=225,91 \%$ and $175,70.1 \%$ respectively). As for sexual relations, the most common risky behaviour was unprotected $\operatorname{sex}(n=201,81.4 \%)$. Financial needs were the major causes of prostitution $(n=71,28.7 \%)$ and the most 
important factor that deterred subjects from engaging in prostitution was the lack of any financial problems ( $n=11,4.4 \%)$ (Table II).

As for the question exploring individual needs of participants, a significant number stated that they need a job and better education.

Table III shows that the incidence of high-risk behaviours, substance abuse, and the state of physical health and infectious diseases are significantly correlated with mental disorders $(p<0.05)$.

The incidence of mental illnesses (which are not severe enough to warrant exclusion from this study) and substance abuse are two important factors that affect the tendency of homeless individuals for prostitution. We also found that as the age of participants increases by each class (the decade classification in Table I), the risk of prostitution is increased 3-fold (Table IV).

\section{- Discussion}

This study aims to investigate sex-related behaviours among homeless men in Tehran, and also aims to determine the risk factors and variables related to prostitution among the homeless. The term "homelessness" in this study particularly applies to those living in the temporary accommodation centres provided by the municipality of Tehran (public and private sectors) in southern Tehran. Individuals can stay in these shelters for as long as they need and be fed, whether they are sober or under the influence of any substance though no housing is offered to family members of these individuals. Although homelessness is a multi-factorial issue, the results of this study suggested that the major causes of homelessness are substance abuse and low income, which is aligned with the findings reported by Sarvestani et al. regarding the causes of homelessness in Tehran [22]. In Iran, some male prostitutes provide sexual services to men, and a few to women $[6,7,9]$. We found that prostitution was closely related to addiction, mental health illnesses, poor physical condition and a history of viral infections.

Although international studies show that the stigma of prostitution can change people's perspectives towards this population, or in some cases may result in judgment and mistreatment (even from healthcare workers and doctors), some prostitutes claim that the financial gain of the act makes up for the weight of the stigma [8].
Homeless individuals often fall victim to substance abuse, high-risk sexual behaviours and mental health problems [23]. The daily use of various substances also compromises the financial status of these individuals. Moreover, some of these people engage in sexual relations following substance abuse, which is an act, most commonly associated with high-risk sexual behaviour, carried out under and because of the influence of these substances [24]. According to our findings, about $10 \%$ of subjects have had anal sex after drug use. The homeless who are socially isolated or struggle with depression are more likely to engage in acts of prostitution [25]. In the same vein, the findings revealed that the desire for intimacy coupled with social isolation, or trouble in socialising with women, are other major factors contributing to prostitution in homeless individuals [26].

Frequent intravenous injections of psychoactive substances are also one of the contributory factors for engaging multiple sexual partners; on top of that, the partners of these individuals are also commonly grappling with substance abuse, and they usually do not use condoms during sexual intercourse $[15,16]$. In the present study, $81.4 \%$ $(n=201)$ of subjects declared that they did not use a condom in an attempt to feel more pleasure. Participants were mostly in their 30 s and the highest frequency of prostitution was observed in this age group. We found that as the age of participants increases by one class (the decade classification in Table I), the risk of prostitution is increased 3-fold (Table IV). A similar study illustrated that as men get older, they are more likely to engage in prostitution [27]. In accordance to our findings, an American study has shown that psychological issues and substance abuse play a central role in individuals' tendency towards prostitution [28]. For people living in the temporary shelters, the direct supervision of the Welfare Organization of Iran acts as a protective factor, making them less susceptible to mental illnesses. Furthermore, it also increases their chances of finding a reputable job and a healthy source of income.

As noted in a previous study, the Iranian homeless have a preference for methamphetamine, cigarettes and heroin [3], which is consistent with the findings of this study. Heroin is the main cause of death among the homeless [29]. Since injection is the most common route of heroin administration, these people are at a high risk for HIV 
infection [30]. Although addiction is associated with high-risk sexual behaviours, some homeless individuals are unwillingly involved in street prostitution [31, 32]. International studies have demonstrated addiction promotes homelessness, mental health disorders, worse physical health and increased infections in men $[19,31,32]$. As was shown in our results, these phenomena tend to co-exist though it is not clear whether substance abuse is the source or cause of homelessness. As it appears, these two conditions reinforce each other in severity in a vicious cycle. In addition, the specific substance, route of administration, and dosage are some of the key factors that affect the tendency of individuals to engage in high-risk sexual behaviours [32] while using methadone, as a replacement for opioid addiction, changes the method of substance abuse for the better with lower health risks $[6,13]$. However, it is particularly challenging to limit high-risk sexual behaviours in light of frequent anal sex (especially after using amphetamines), low self-esteem, lack of assertiveness, bad decision making skills, inefficient communication skills, low level of education and a history of mental disorders (in up to $45 \%$ of cases) $[16,19,33]$. If participants are adequately motivated to change, this plan can offer successful outcomes [34]. In recent years, the "Social Security Coefficient Program" has commenced to help the homeless in Tehran. In this programme, these individuals are identified and provided with methadone maintenance treatment (MMT) programme. Furthermore, the treatment offered at these centres can significantly reduce engagement in high-risk sexual behaviours [35].

Prostitution is one of the major sources of income for the homeless, especially those who are also addicted to various substances and are less likely to be able to hold down a job [36]. Homelessness gives rise to a plethora of health problems in individuals and society. The provision of medical services in temporary shelters can hamper the hospitalisation of homeless people. The mental health supportive programmes like a comprehensive assertive community treatment (ACT) programme, addiction control programmes, and basic skills training programmes that meet the fundamental health-related needs of homeless people, can be effective strategies in controlling physical and infectious diseases that harm this population [37].
In our study, $17 \%$ of subjects suffered from depression and $21.8 \%$ had a history of attempted suicide. According to the results of a study on the life expectancy of homeless people in Tehran, the effect of "homelessness" on life expectancy is mediated with factors like mental illness, acute addiction to opiates and attempted suicide [38].

Our study showed that homelessness can be rooted in a myriad of familial issues that, for the most part, are connected to financial problems and family disputes. Related international studies that have investigated homelessness in youth, report childhood traumas and negative experiences at home to be some of the major contributing factors in homelessness [8], which shows a significant shift from issues at home to financial pressure as reasons for prostitution as individuals enter adulthood.

To the best of our knowledge, few studies have explored homeless male prostitutes in Iran. Hence, our sources are very limited and confined to a handful of published reports and interviews. As such, more relevant studies on factors that contribute to the growth of the population of male homeless prostitutes seem necessary. The main limitation of this study is that although temporary shelters are designed to prevent the spread of other social harms among homeless people, the effect of "social learning" as a potential interfering factor cannot be overlooked.

Mental health supportive programmes, a comprehensive assertive community treatment (ACT) programme, addiction control programmes and basic skills training programmes that meet the fundamental health-related needs of homeless people, can be effective strategies in controlling the physical trauma and infectious diseases that are associated with addiction and prostitution [37]. We believe that by provision of proper inhabitation, social support, medical services and enough job opportunities, homeless people could be protected from mental health disorders and drug abuse, which will decrease the rate of high-risk sexual behaviours.

\section{- CONCLUSIONS}

Complicated by the growth of the homeless population, prostitution can spawn a myriad of other harms such as the transmission of HIV/ 
AIDS and hepatitis. A number of factors like substance abuse, mental health disorders, physical trauma and infection are associated with a higher incidence of this phenomenon. However, the in- habitation of these vulnerable individuals at emergency shelters and provision of social support and medical services can protect them from mental disorders and substance abuse.

\section{Conflict of interest/Konflikt interesów}

None declared./Nie występuje.

\section{Financial support/Finansowanie}

This study was funded by:/Praca została sfinasowana przez: the Student Research Committee of Mazandaran University of Medical Sciences, Iran: "Prostitution and the factors affecting it among homeless men in Tehran", grant no 114 of 2018.

\section{Ethics/Etyka}

The work described in this article has been carried out in accordance with the Code of Ethics of the World Medical Association (Declaration of Helsinki) on medical research involving human subjects, Uniform Requirements for manuscripts submitted to biomedical journals and the ethical principles defined in the Farmington Consensus of 1997.

Treści przedstawione w pracy są zgodne z zasadami Deklaracji Helsińskiej odnoszącymi się do badań z udziałem ludzi, ujednoliconymi wymaganiami dla czasopism biomedycznych oraz z zasadami etycznymi określonymi w Porozumieniu z Farmington w 1997 roku.

\section{References/Piśmiennictwo}

1. Tsai J, O'Toole T, Kearney LK. Homelessness as a public mental health and social problem: New knowledge and solutions. Psychological Services 2017; 14: 113.

2. Springer S. Homelessness: a proposal for a global definition and classification. Habitat International 2000; 24: 475-84.

3. Sajjadi S, Kamal SHM, Darzi HA. The socioeconomic status of street homeless in Tehran. Adv Environ Biol 2014; 6: 1297-304.

4. Zadeh AOT, Seyed Alinaghi S, Hassanzad FF, Hajizadeh M, Mohamadi S, Emamzadeh-Fard S, et al. Prevalence of HIV infection and the correlates among homeless in Tehran, Iran. Asian Pac J Trop Biomed 2014; 4: 65-8.

5. Fazel S, Geddes JR, Kushel M. The health of homeless people in high-income countries: descriptive epidemiology, health consequences, and clinical and policy recommendations. Lancet 2014; 384: 1529-40.

6. Hsu HT, Wenzel S, Rice E, Gilreath TD, Kurzban S, Unger J. Understanding consistent condom use among homeless men who have sex with women and engage in multiple sexual partnerships: a path analysis. AIDS Behav 2015; 19: 1676-88.

7. Ghaderi S, Naroghe NA, Mosallai SM. The status of drug abuse in addicted sex worker women in Tehran in 1392 [2013]. Quarterly of Policing Knowledge of the Capital Police 2016; 9: 77-95.

8. Heerde JA, Scholes-Balog KE, Hemphill SA. Associations between youth homelessness, sexual offenses, sexual victimization, and sexual risk behaviors: a systematic literature review. Arch Sex Behav 2015; 44: 181-212.

9. Vahdani P, Hosseini MS, Famili A, Moheb DR. Prevalence of HBV, HCV, HIV, and syphilis among homeless subjects older than fifteen years in Tehran. Arch Iran Med 2009; 12: $483-7$.

10. Iram T, Ilyas M, Bilal AR, Parveen S, Chan HC. Socioeconomic acceptability of prostitutes in Pakistan: A diversion from prostitution. Cogent Social Sciences 2019; 5: 1646110. 
11. Erickson PG, Butters J, McGillicuddy P, Hallgren A. Crack and prostitution: gender, myths, and experiences. Journal of Drug Issues 2000; 30: 767-88.

12. Hounmenou C. An initial exploration of prostitution of boys in the West African region. Child Abuse Negl 2017; 69: 188-200.

13. Ecker J, Cherner R, Rae J, Czechowski K. Sexual intimacy, mental illness, and homelessness. Am J Community Psychol 2018; 61: 131-40.

14. Brown RA, Kennedy DP, Tucker JS, Wenzel SL, Golinelli D, Wertheimer SR, et al. Sex and relationships on the street: how homeless men judge partner risk on Skid Row. AIDS Behav 2012; 16: 774-84.

15. Mirnaseri S, Poustchi H, Naseri MS, Tavakoli H, Mohammad KA, Afshar P, et al. Hepatitis C seroprevalence among intravenous drug users in Tehran. Journal of Research in Medical Sciences 2008; 6: 295-302.

16. Calsyn DA, Campbell AN, Crits-Christoph P, Doyle SR, Tross S, Hatch-Maillette MA, et al. Men in methadone maintenance versus psychosocial outpatient treatment: differences in sexual risk behaviors and intervention effectiveness from a multisite HIV prevention intervention trial. $J$ Addict Dis 2010; 29: 370-82.

17. Noroozi M, Ahmadi S, Armoon B, Jorjoran Shushtari Z, Sharhani A, Ahounbar E, et al. Social determinants associated with risky sexual behaviors among men who inject drugs in Kermanshah, Western Iran. Journal of Substance Use 2018; 23: 591-6.

18. MacArthur GJ, Minozzi S, Martin N, Vickerman P, Deren S, Bruneau J, et al. Opiate substitution treatment and HIV transmission in people who inject drugs: systematic review and meta-analysis. $B M J$ 2012; 345: e5945.

19. Taghizadeh H, Taghizadeh F, Fathi M, Reihani P, Shirdel N, Rezaee SM. Drug use and high-risk sexual behaviors of women at a drop-in center in Mazandaran Province, Iran, 2014. Iranian J Psychiatry Behav Sci 2015; 9: e1047.

20. Fleiss JL, Levin B, Paik MC. Statistical methods for rates and proportions. $3^{\text {rd }}$ ed. Hoboken: John Wiley \& Sons; 2003.

21. Glynn R, Laird N. Regression estimates and missing data: complete case analysis. Cambridge MA: Harvard School of Public Health, Department of Biostatistics; 1986.

22. Savestani RS, Nasr Esfahani A. Drug abuse, social exclusion and homeless in Tehran: a qualitative study. Iranian Journal of Social Problems 2010; 1: 1-18 [In Persian].

23. Gattis MN. Psychosocial problems associated with homelessness in sexual minority youths. Journal of Human Behavior in the Social Environment 2009; 19: 1066-94.

24. Petering R. Sexual risk, substance use, mental health, and trauma experiences of ganginvolved homeless youth. Journal of Adolescence 2016; 48: 73-81.

25. Tucker JS, Wenzel SL, Kennedy DP, Golinelli D, Ewing B. Sex trade behavior among heterosexually active homeless men. Archives of Sexual Behavior 2013; 42: 1535-44.

26. Goldenberg SM, Strathdee SA, Gallardo M, Rhodes T, Wagner KD, Patterson TL. "Over here, it's just drugs, women and all the madness": The HIV risk environment of clients of female sex workers in Tijuana, Mexico. Social Science \& Medicine 2011; 72: 1185-92.

27. Reid JA, Piquero AR. Age-graded risks for commercial sexual exploitation of male and female youth. Journal of Interpersonal Violence 2014; 29: 1747-77.

28. Zuvekas SH, Hill SC. Income and employment among homeless people: the role of mental health, health and substance abuse. The Journal of Mental Health Policy and Economics 2000; 3: 153-63.

29. Baggett TP, Chang Y, Singer DE, Porneala BC, Gaeta JM, O'Connell JJ, et al. Tobacco-, alcohol-, and drug-attributable deaths and their contribution to mortality disparities in a cohort of homeless adults in Boston. Am J Public Health 2015; 105: 1189-97.

30. Wilkerson JM, Noor SW, Breckenridge ED, Adeboye AA, Rosser BS. Substance-use and sexual harm reduction strategies of methamphetamine-using men who have sex with men and inject drugs. AIDS Care 2015; 27: 1047-54.

31. Heerde JA, Hemphill SA. Sexual risk behaviors, sexual offenses, and sexual victimization among homeless youth: A systematic review of associations with substance use. Trauma Violence Abuse 2016; 17: 468-89. 
32. Heerde JA, Hemphill SA. A systematic review of associations between perpetration of physically violent behaviors and property offenses, victimization and use of substances among homeless youth. Children and Youth Services Review 2014; 44: 265-77.

33. Paul JP, Stall R, Davis F. Sexual risk for HIV transmission among gay/bisexual men in substance-abuse treatment. AIDS Educ Prev 1993; 5: 11-24.

34. Arasteh K, Des Jarlais DC, Perlis TE. Alcohol and HIV sexual risk behaviors among injection drug users. Drug Alcohol Depend 2008; 95: 54-61.

35. Ekhtiari H, Safaei H, Mokri A, Mahin Torabi S. Is there a clear relationship between demographic characteristics and impulsivity indices in human immunodeficiency virus infection among IDUs. Social Welfare 2011; 9: 207-21 [In Persian].

36. Gomez R, Thompson SJ, Barczyk AN. Factors associated with substance use among homeless young adults. Substance Abuse 2010; 31: 24-34.

37. Hwang SW, Burns T. Health interventions for people who are homeless. Lancet 2014; 384: 1541-7.

38. Safiri KK, Khadem R. Study of the status of hope in life in homeless women in Tehran. Journal of Iranian Social Development Studies 2014; 6: 51-70 [In Persian]. 